\title{
Application and Analysis for Ground Water Heat Pump System of a University in Tianjin
}

\author{
Jingbo Liu ${ }^{1, a^{*}}$, Yingni Jiang ${ }^{1, b}$, Zhengguo Gong ${ }^{1, c}$ and Hao Yang ${ }^{1, d}$ \\ ${ }^{1}$ Architecture Engineering Department, Logistics University of PAP. Tianjin, China \\ a568818102@qq.com, bjyingni@sina.com, ${ }^{c} 782101251 @ q q . c o m,{ }^{d} 849253712 @ q q . c o m$
}

Keywords: GWHP; Comparative analysis; Economy; Application

\begin{abstract}
A ground water heat pump system (GWHP) of a university in Tianjin was introduced, and the system was compared with the other two heating and cooling systems in this paper. The initial and operating cost was calculated, and then the advantages and disadvantages of the systems were analyzed. The results show that the GWHP system makes full use of geothermal energy, and it is better than the other two systems in economy and application.
\end{abstract}

\section{Introduction}

With the rapid development of our society and economy, there comes a large energy demand and the serious environmental pollution. It is imperative to develop some new clean and efficient energies. As one of the most promising energies, geothermal energy is rich and in huge reserves in our country [1]. GWHP is a new technology which extracts the energy of the earth, and then releases the energy to cool or heat buildings. The technology with great potential has been widely used in hospitals, schools and other public buildings. There are broad discussions and researches on the technology, and it has great practical significance to utilizing the energy and solving the environmental problem [2].

\section{Working Principle}

The GWHP is an efficient HAVC system. It extracts the geothermal energy contained in the water, and then releases the energy to realize heating and cooling [3,4]. It is a new type of high grade energy saving technology, which pumps low-grade heat into high-grade thermal energy. The system is usually consisted of three parts: outdoor geothermal heat exchanger system, water source heat pump unit and indoor air-conditioning terminal system [5,6].

Working principle of GWHP can be described that extracting geothermal energy as the heat source to increase indoor temperature in winter and storing the indoor heat into earth in summer [7]. This form of energy supplies little pollution to environment, and mostly, users can get more than 4 $\mathrm{kWh}$ of heating or cooling capacity by consuming $1 \mathrm{kWh}$ of power [8].

\section{Application Case}

Introduction of an Actual Project. The project is located in a university of Tianjin. The total floor area of the university is 210,000 square meters and a planned cooling and heating area is about 175,000 square meters. The domestic hot water is supplied by two geothermal wells. One is used to pumping and another to injecting. The depth of the two wells is 2500 meters. The water yield of the pumping well is $90 \mathrm{~m} 3 / \mathrm{h}$. Outlet temperature of geothermal water is $90^{\circ} \mathrm{C}$, while through the plate heat exchanger, the temperature turns into about $62^{\circ} \mathrm{C}$.

Heating and cooling are realized by a GWHP system, the maximum heating load is $4000 \mathrm{kw}$ in winter and the cooling load is $6200 \mathrm{kw}$ in summer. The GWHP system supplies heat or refrigeration in an indirect way: geothermal water transfers heat to the circulating water of heating pipe network through a plate heat exchanger, and after its temperature declined, geothermal water will be back into a injection well. The device room of the system is located in the underground of 
dining room which was consisted of one screw ground source heat pump units and 3 sets of centrifugal ground source heat pump units. Those devices provide refrigeration in summer and heating in winter for the entire campus buildings.

Refrigerate conditions: inlet and outlet temperature of cooling water is $13 / 6^{\circ} \mathrm{C}$, inlet and outlet temperature of the condenser is $30 / 35^{\circ} \mathrm{C}$; heating conditions: input and outlet temperature of hot water is $38 / 45^{\circ} \mathrm{C}$, inlet and outlet temperature of the evaporator is $9 / 5^{\circ} \mathrm{C}$; The total power of the system is $3397.8 \mathrm{kw}$.

The Simulation Schemes. There are three common methods of utilizing energy to supply heat and refrigeration at present, including the direct use of the municipal heating, the exploitation of geothermal energy and the use of natural gas. The economy and practicability of cooling and heating schemes are analyzed between the actual project and two simulation schemes, and the simulation schemes are shown blow.

Plan a: Central-heating and central-cooling. Domestic hot water is supplied by both gas boiler and solar energy. In this plan, the university will get heat supplied by the municipal heating in winter and get refrigeration supplied by the refrigeration station in summer.

Plan b: Gas direct-fired machines were used to supply domestic hot water, heat and refrigeration. In this plan all energy will be provided by gas direct-fired machines.

Comparison and Analysis on Simulation Schemes. Initial and operating costs were used to be the major factors of economic comparison. The total initial cost includes the basic system, hot water system and the terminal system. And the costs of practical and simulation schemes are shown in Table 1-3.

Table 1 Initial cost of the actual project

\begin{tabular}{|c|c|c|c|}
\hline Item & Area[m $\left.{ }^{2}\right]$ & Unit price[Y $\left./ \mathrm{m}^{2}\right]$ & $\begin{array}{c}\text { Total price } \\
{[1000 Y]}\end{array}$ \\
\hline $\begin{array}{c}\text { Cost of geothermal well } \\
\text { system }\end{array}$ & 2,500 & 2,600 & 1,300 \\
\hline $\begin{array}{c}\text { Cost of domestic hot } \\
\text { water system }\end{array}$ & $\begin{array}{c}3 \text { GWHPs; 24 circulating water } \\
\text { pumps; 6 plate heat exchangers and } \\
\text { pipelines; 4 domestic hot water pumps; } \\
\text { drilling system }\end{array}$ & 1,000 \\
\hline $\begin{array}{c}\text { Cost of refrigeration } \\
\text { station }\end{array}$ & & 23,000 \\
\hline Total & & 25,300 \\
\hline
\end{tabular}

Table 2 Initial cost of Plan a

\begin{tabular}{|c|c|c|c|}
\hline Item & Area $\left[\mathrm{m}^{2}\right]$ & Unit price[Y $\left./ \mathrm{m}^{2}\right]$ & $\begin{array}{c}\text { Total price } \\
{[1000 Y]}\end{array}$ \\
\hline Cost of heat & 174,916 & 130 & 22,730 \\
\hline $\begin{array}{c}\text { Cost of domestic hot } \\
\text { water system }\end{array}$ & gas-fired boiler and solar energy & 4,500 \\
\hline $\begin{array}{c}\text { Cost of refrigeration } \\
\text { station }\end{array}$ & $\begin{array}{c}6 \text { centrifugal refrigeration machines } \\
14 \text { circulating water pumps, 4 cooling } \\
\text { towers, 4 plate heat exchangers and } \\
\text { pipelines, 4 domestic hot water pumps }\end{array}$ & 18,200 \\
\hline Total & & 45,430 \\
\hline
\end{tabular}


Table 3 Initial cost of Plan b

\begin{tabular}{|c|c|c|}
\hline Item & & $\begin{array}{c}\text { Total price } \\
{[1000 ¥]}\end{array}$ \\
\hline $\begin{array}{c}\text { Cost of domestic hot } \\
\text { water system }\end{array}$ & 58,000 \\
\hline $\begin{array}{c}\text { Cost of refrigeration } \\
\text { station }\end{array}$ & $\begin{array}{c}\text { 6 gas-fired machines, 16 set of plate } \\
\text { heat exchangers and pipelines, } \\
\text { 4 domestic hot water pumps }\end{array}$ & 2,000 \\
\hline Total & & 60,000 \\
\hline
\end{tabular}

When the circulating system of GWHP running, heat can be transferred from underground to the indoor in winter and reversed back in summer. The main consumption of energy is electric energy which is used as driving forces in heat-pump compressor, circulating pump and fan blower. The electric energy is the main part of the energy consumption and it constitutes the mainly operating cost. So the electric charge is regarded as the main operating cost in the following, and the payment for municipal heating and natural gas is regarded as the operating cost of the other two simulation schemes, respectively. The electricity price is 0.49 yuan per kilowatt-hour and the gas price is 2.8 yuan per cubic meter.

The operating cost of the actual project was 170 thousand yuan in winter and the charge of geothermal water is 0.3 yuan per ton. The calculation results are shown in Table 4.

Table 4 The operating cost of the actual project in winter

\begin{tabular}{|c|c|c|c|c|}
\hline $\begin{array}{c}\text { Category } \\
{[\text { load] }}\end{array}$ & $\begin{array}{c}\text { Days of } \\
\text { operating } \\
\text { [day] }\end{array}$ & $\begin{array}{c}\text { Daily cost of heat } \\
\text { pump system } \\
{[1000 ¥]}\end{array}$ & $\begin{array}{c}\text { Total cost of heat } \\
\text { pump system } \\
{[1000 ¥]}\end{array}$ & $\begin{array}{c}\text { Cost of } \\
\text { geothermal water }\end{array}$ \\
\hline $100 \%$ & 10 & 1.36 & 13.6 & 1.05 \\
\hline $80 \%$ & 30 & 1.09 & 31.6 & 2.51 \\
\hline $60 \%$ & 40 & 0.82 & 31.6 & 2.51 \\
\hline $40 \%$ & 30 & 0.54 & 15.3 & 1.14 \\
\hline $20 \%$ & 10 & 0.27 & 2.7 & 0.21 \\
\hline total & 120 & & 94.8 & 7.52 \\
\cline { 3 - 5 } & & & \multicolumn{2}{|c|}{170} \\
\hline
\end{tabular}

Tianjin has four distinct seasons. The period of cooling days in summer and heating days in winter are the same, which are 120 days, meanwhile there is little difference between the operating cost in winter and in summer. The operating costs of the actual project and the other simulation schemes are shown in Table 5-7.

Table 5 The operating cost of the practical scheme

\begin{tabular}{|c|c|c|c|}
\hline Season & Cost $[¥ / \mathrm{m} 2]$ & Total cost $[1000 ¥]$ & $\begin{array}{c}\text { Total } \\
{[1000 Y]}\end{array}$ \\
\hline Winter & 17 & $175^{*} 17=2975$ & $2975+2975=5950$ \\
\hline Summer & 17 & $175^{*} 17=2975$ & 2975 \\
\hline
\end{tabular}

Table 6 The operating cost of plan a

\begin{tabular}{|c|c|c|c|}
\hline Season & Cost $[¥ / \mathrm{m} 2]$ & Total cost $[1000 ¥]$ & $\begin{array}{c}\text { Total } \\
{[1000 ¥]}\end{array}$ \\
\hline Winter & 36 & $175^{*} 36=6300$ & \multirow{2}{*}{$6300+3150=9450$} \\
\hline Summer & 18 & $175^{*} 15=3150$ & \\
\hline
\end{tabular}


Table 7 The operating cost of plan b

\begin{tabular}{|c|c|c|c|}
\hline Season & Cost[Y/m2] & Total cost $[1000 Y]$ & $\begin{array}{c}\text { Total } \\
{[1000 Y]}\end{array}$ \\
\hline Winter & 32 & $175^{*} 32=5600$ & $5600+4375=9975$ \\
\hline Summer & 25 & $175^{*} 25=4375$ & 560 \\
\hline
\end{tabular}

It can be seen from the result that the cost of the actual project is lower than the simulation schemes, both the initial cost and the operating cost of the GWHP system are far less than those of the municipal heating or gas heating.

Contrast Analysis of Applications. Compared with the practical scheme, the two simulation schemes have shortcomings not only in economy, but also in application.

In plan a, the heat needs to be supplied by municipal heating in winter and the device for cooling is also need to be installed in summer. Those devices are expensive, moreover, the cooling devices are leaved unused in winter. The autonomy of using energy is restricted because of municipal heating. Compared with GWHP system, the university can't timely open or close the heat source according to the varying weather conditions in spring and autumn, which will make campus life relatively inconvenient. Affected by heating distance, layout of pipes and other factors, the heating effect is not well guaranteed. And an additional hot water system is also need to be installed for daily bathing.

In plan $b$, the university have to build a large gas station to support gas direct-fired machines, which supply domestic water, heat and refrigeration. Moreover, there is a certain effect on the environment. The system must be dangerous because of its location in campus. Once a security accident happened, the consequences would be serious. Under the the shortage of energy, the fuel is difficult to be obtained. Besides, attenuation rate of direct-fired machine unit is very high, as the time goes on, heating or cooling performance of the unit will be greatly weakened.

\section{Conclusion}

It can be seen that the use of GWHP system is the optimal scheme to solve the problem of heating and cooling in this project. The system reasonably utilizes plenty of geothermal resources, reduces the cost, meets the actual requirements of cooling and heating, and makes the maximum benefits. This project of GWHP for heating and cooling is a successful scheme. The system has the characteristics of small management cost, stable operation and efficient effect.

\section{References}

[1] Y.D. Cai, D.F. Lin and M.F. Xu: The present research situation and application prospect of geothermal air conditioning, Energy Conservation 11 (2012) ,7-9.

[2] R.S. Zhang: Ground source heat pump heating economic energy conservation and environmental protection, Qilu Evening News (2013)

[3] Y.H. Wang, Y.M. Chen: Research and application of ground source heat pump, Building Energy \& Environment, Vol.23, (2014)No4, 30-35.

[4] Y.X. Q: Modeling and Simulation of ground source heat pumps system (Ph.D., Xi'an University Of Architecture And Technology, China 2008), p.28.

[5] Y.M. Tian, X.H.Zhao: Optimization of unified planning of urban water supply and intermediate water systems, Water Supply and Drainage. Vol.27, (2013)No5, 23-26.

[6] G.N. Tang: Research on the application of ground source heat pump, Environmental Protection and Circular Economy. Vol.27, (2013)No5, 34-37. 
[7] L.Fei: Research on Inverse Model and Energy Efficiency of Installed Ground Source Heat Pump Systems (Ph.D., Huazhong University of Science \& Technology, China 2011), p.26.

[8] X.H. Wu: Research and Simulation Analysis of Combing Solar Collector and Ground Source Heat Pump System Heating (Ph.D., Jilin University, China 2012), p.23. 